\title{
Evaluasi Penerapan Kerjasama Pemerintah - Swasta Dalam Pembangunan Dan Pengelolaan Pasar Desa Penyangkringan - Weleri - Kabupaten Kendal (Tinjauan Aspek Finansial Dan Aspek Ekonomi)
}

\author{
Ryan Rahutama
}

Diterima : 5 September 2016

Disetujui : 8 Desember 2016

\begin{abstract}
Penyangkringan villages became one village into the Center for Environmental Activities (PKL) to the service center functions as a center of trade and services in accordance with the Spatial Kendal Year 2011-2031. The village where Penyangkringan have potential cash asset village that has not been optimally and can not accommodate these activities so that the village government plans to build a village market. But with a limited budget, cooperation with the private sector to be the solution to overcome it. Authorities village rural market development cooperation with built-operate-transfer (BGS) with a contract term of 10 years. Therefore we need a study evaluating the implementation of the cooperation that focus on the financial feasibility and economic aspects. The purpose of this study was to evaluate the implementation of village government and private partnership in the development of rural markets in financial aspects and economic aspects. Financial and economic aspects views of four criteria: Net Present Value (NPV), Internal Rate of Return (IRR), Benefit Cost Ratio (BCR), and Pay Back Period (PBP). The results showed that the financial results obtained Rp. 193.610.176 (NPV), 13,5\% (IRR), 1,035 (BCR), and 4 Years, 3 Months (PBP), while economically the results obtained Rp. 143.437.317 (NPV), $11,6 \%$ (IRR), 1,01 (BCR) and 4 Years, 4 Months (PBP)
\end{abstract}

Keywords : Public Private Partnership, Village Market, Financial Feasibility, Economic Feasibility

\begin{abstract}
ABSTRAK
Desa Penyangkringan menjadi salah desa yang menjadi Pusat Kegiatan Lingkungan (PKL) dengan fungsi pusat pelayanan sebagai pusat perdagangan dan jasa sesuai dengan RTRW Kabupaten Kendal Tahun 20112031. Dimana Desa Penyangkringan mempunyai potensi aset kas desa yang belum termanfaatkan secara optimal dan belum dapat mewadahi aktifitas tersebut sehingga pemerintah desa berencana membangun pasar desa. Tetapi dengan keterbatasan anggaran maka kerjasama dengan pihak swasta menjadi solusi untuk mengatasinya. Pihak pemerintah desa melakukan kerjasama pembangunan pasar desa dengan metode bangun-guna-serah (BGS) dengan masa kontrak selama 10 tahun. Oleh karena itu diperlukan suatu penelitian evaluasi penerapan kerjasama tersebut yang fokus pada aspek kelayakan finansial dan aspek ekonomi. Tujuan penelitian ini adalah untuk mengkaji penerapan kerjasama pemerintah desa dan swasta dalam pembangunan pasar desa ditinjau aspek finansial dan aspek ekonomi. Aspek finansial dan ekonomi dilihat dari empat kriteria yaitu Net Present Value (NPV), Internal Rate of Return (IRR), Benefit Cost Ratio (BCR) dan Pay Back Period (PBP). Hasil penelitian menunjukkan bahwa secara finansial didapatkan hasil Rp. 193.610.176 (NPV), 13,5\% (IRR), 1,035 (BCR), dan 4 Tahun 3 Bulan (PBP) sedangkan secara ekonomi didapatkan hasil Rp. 143.437.317 (NPV), 11,6\% (IRR), 1,01 (BCR) dan 4 Tahun 4 Bulan (PBP).
\end{abstract}

Kata Kunci : Kerjasama Pemerintah -Swasta, Pasar Desa, Kelayakan Finansial, Kelayakan Ekonomi 
JPWK 12 (4) Rahutama, R. | Evaluasi Penerapan Kerjasama Pemerintah-Swasta Dalam Pembangunan Dan Pengelolaan Pasar Desa Penyangkringan - Weleri - Kabupaten Kendal ( Tinjauan Aspek Finansial Dan Aspek Ekonomi )

\section{PENDAHULUAN}

Salah satu daerah yang menjadi pusat pelayanan di Kabupaten Kendal adalah Kecamatan Weleri. Sesuai dengan RTRW Kabupaten Kendal Tahun 2011-2031 bahwa Kecamatan Weleri termasuk dalam Pusat Kegiatan Lingkungan (PKL) dengan fungsi pusat pelayanan sebagai pusat perdagangan dan jasa. Desa Penyangkringan merupakan salah satu desa yang termasuk didalam Pusat Kegiatan Lingkungan (PKL) tersebut. Hal ini dapat dilihat dari adanya sarana-sarana yang mendukung kegiatan tersebut, diantaranya adalah Pasar Weleri 2, bank-bank, serta adanya terminal tipe C. Desa penyangkringan juga dilalui oleh jalan arteri primer (jalur pantura) dan jalan arteri sekunder (jalan menuju ke Kabupaten Temanggung). Selain itu juga terdapat Pasar Desa Penyangkringan yang beroperasi pada tahun 2013, hal ini dapat menambah daya dukung dari Desa Penyangkringan dalam menyokong kegiatan perdagangan dan jasa yang ada. Pasar desa tersebut merupakan inisiatif dari Pemerintah Desa Penyangkringan yang melihat potensi yang dimiliki pihak pemerintah desa yang dapat lebih dioptimalkan didalam memberikan manfaat terhadap pihak pemerintah desa maupun masyarakat secara umum. Pasar desa dibangun sebagai solusi didalam mewadahi aktifitas perdagangan dan jasa yang ada berupa lapak-lapak pedagang kaki lima yang menyebabkan kesan kumuh, jorok, dan semrawut.

Pasar Desa Penyangkringan merupakan bentuk dari kerjasama pemerintah dan swasta sesuai dengan UU no 6 Tahun 2014 dimana Pemerintah Desa mempunyai kewenangan yang lebih luas didalam usaha meningkatkan kesejahteraan masyarakatnya dan Peraturan Menteri Dalam Negeri No 7 Tahun 2007 tentang Pedoman Pengelolaan Kekayaan Desa menjelaskan bahwa Pemerintah Desa dapat mengelola aset yang ada dengan melakukan kerjasama dengan pihak swasta. Kerjasama tersebut dilakukan karena adanya keterbatasan anggaran dari pemerintah desa yang tertuang didalam perjanjian No. 143/MoU/V/2013/Penyangkringan dan No. 17/MoU/KAS/V/2013 tentang Pemanfaatan Tanah Kas Desa Penyangkringan Kecamatan Weleri (Bangun-Guna-Serah) Untuk Pembangunan Pasar desa Penyangkringan Kecamatan Weleri. Hal tersebut didukung dengan adanya aset desa yang berada dilokasi strategis dan berada pada pusat perdagangan dan jasa.

Selain itu pemerintah desa membangun pasar desa karena adanya pemanfaatan lahan atau aset desa yang tidak sesuai peruntukannya dan belum optimalnya pemanfaatan aset desa sebagai sumber pendapatan desa. Kerjasama yang ada berjangka waktu selama 10 tahun dari tahun 2013 - 2023. Untuk itu perlu adanya evaluasi mengenai penerapan kerjasama tersebut dan kelayakan pembangunan dan pengelolaan pasar desa yang ditinjau dari aspek finansial serta aspek ekonomi.

\section{METODOLOGI PENELITIAN}

Pendekatan yang dilakukan didalam penelitan ini menggunakan pendekatan positivisme. Pendekatan tersebut digunakan karena variabel yang akan diteliti dapat diamati dan diukur. Pengamatan yang dilakukan dengan observasi lapangan yang akan mengamati gejala atau fenomena yang terjadi dilapangan. 
Rahutama, R. | Evaluasi Penerapan Kerjasama Pemerintah-Swasta Dalam Pembangunan Dan Pengelolaan Pasar Desa Penyangkringan - Weleri - Kabupaten Kendal ( Tinjauan Aspek Finansial Dan Aspek Ekonomi )

JPWK 12 (4)

Metode yang dilakukan dalam penelitian ini merupakan penelitian dengan metode kuantitatif. Dimana metode kuantitatif deskriptif dapat menjelaskan proses dari kerjasama pemerintah Desa Penyangkringan dan pihak swasta yaitu PT. Kharisma Agung Sentosa dan kaitannya dengan pedagang pada lokasi tersebut serta digunakan didalam menjelaskan kerjasama pemerintah dan swasta yang dilakukan ditinjau dari aspek finansial dan aspek ekonomi sehingga pendekatan tersebut dapat menjadi bahan pertimbangan didalam penentuan kerjasama berikut jangka waktunya yang menggunakan skema BGS.

Teknik pengambilan sampel pada penelitian ini menggunakan teknik non-probability sampling yang digunakan terdiri dari dua yaitu Teknik purposive sampling dan teknik sampling sistematis, dimana jumlah sampel dari penelitian ini yaitu 51 sampel.

Teknik analisis yang digunakan adalah statistik deskriptif. Dimana statistik deskriptif adalah statistik yang digunakan untuk menganalisis data dengan cara mendeskripsikan atau menggambarkan data yang telah terkumpul sebagaimana adanya tanpa bermaksud membuat kesimpulan yang berlaku untuk umum (Sugiyono, 2012).

\section{GAMBARAN UMUM WILAYAH STUDI}

Luas wilayah Desa Penyangkringan yaitu seluas $1,78 \mathrm{Km}^{2}$ atau sekitar $177.850 \mathrm{Ha}$, dengan penggunaan lahanya mayoritas sebagai sebagai lahan terbangun yaitu rumah dan bangunan lainnya. Hal ini terkait dengan posisi strategis dari Desa Penyangkringan yang terletak di pusat ekonomi di Kecamatan Weleri serta dilewati oleh jalur pantura dan jalur menuju ke Kabupaten Temanggung dan sekitarnya. Pasar Desa Penyangkringan terletak di pusat perekonomian dari Kecamatan Weleri sehingga mempunyai nilai strategis yang diharapkan akan memberikan manfaat lebih terhadap masyarakat secara umum. Pasar Desa Penyangkringan berupa kios sejumlah 104 kios yang terdiri dari 8 tipe, dimana tipe tersebut berdasarkan ukuran luas kios. Pasar Desa Penyangkringan telah beroperasi mulai tahun 2014 dan akan dikelola oleh pihak investor sampai dengan tahun 2023.

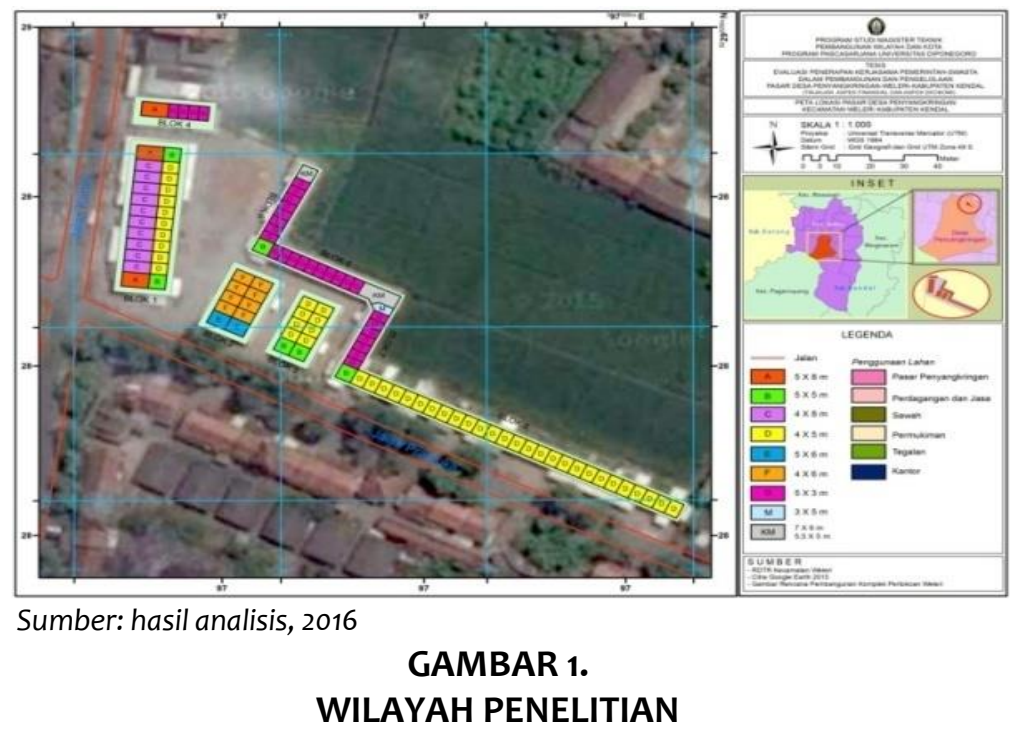


JPWK 12 (4) Rahutama, R. | Evaluasi Penerapan Kerjasama Pemerintah-Swasta Dalam Pembangunan Dan Pengelolaan Pasar Desa Penyangkringan - Weleri - Kabupaten Kendal ( Tinjauan Aspek Finansial Dan Aspek Ekonomi )

\section{Kajian Evaluasi Penerapan Kerjasama Pemerintah-Swasta Dalam Pembangunan Dan Pengelolaan Pasar Desa Penyangkringan-Weleri-Kabupaten Kendal}

Pasar desa merupakan pasar tradisional yang berkedudukan di desa dan dikelola serta dikembangkan oleh pemerintah desa dan masyarakat desa (Peraturan Menteri Dalam Negeri No 42 Tahun 2007) dan menurut Peraturan Menteri Dalam Negeri No 20 Tahun 2012 tentang pengelolaan dan pemberdayaan pasar tradisional bahwa fasilitas bangunan pasar tradisional dan tata letak pasar yaitu: bangunan toko/kios/los dibuat dengan ukuran standar ruang tertentu; petak atau blok dengan akses jalan pengunjung ke segala arah; pencahayaan dan sirkulasi udara yang cukup; penataan toko/kios/los berdasarkan jenis barang dagangan; dan bentuk bangunan pasar tradisional selaras dengan karakteristik budaya daerah. selain itu pasar tradisional mempunyai sarana pendukungnya berupa kantor pengelola; areal parkir; tempat pembuangan sampah sementara/sarana pengelolaan sampah; air bersih; anitasi/drainase; tempat ibadah; toilet umum; pos keamanan; tempat pengelolaan limbah/instalasi pengelolaan air limbah; hidran dan fasilitas pemadam kebakaran; penteraan; sarana komunikasi; dan area bongkar muat dagangan.

Penerapan kerjasama pemerintah dan swasta tidak terlepas dari prinsip, kendala dan faktor keberhasilan yang akan menentukan keberhasilan dari kerjasama yang ada. Prinsip kerjasama didalam Peraturan Presiden No. 67 Tahun 2005 adalah adil, terbuka, transparan, bersaing, bertanggung-gugat, saling menguntungkan, saling membutuhkan, dan saling mendukung. Untuk kendala yang dihadapi (Handley, 1997) adalah kurangnya komitmen antar pemangku kepentingan dalam pelaksanaan proyek, ketidakmampuan memahami alasan dan tujuan proyek dilakukan dengan metode KPS, kurangnya transparasi, penawaran yang kompetitif, atau detail proyek yang akan dikerjakan, serta adanya resiko yang ditanggung pemerintah karena proyek resiko tinggi, sedangkan pihak swasta tetap menuntut imbalan. Sedangkan faktor keberhasilan (Casanova dalam Setiawan dan Sukma, 2012) ada empat yaitu Ekuitas (adil), efektivitas, efisiensi, pelimpahan resiko.

Pembangunan pasar tentu harus mempertimbangkan (Sanusi, 2000, Kadariah, 1999 dan Gray, dkk, 2005) kelayakan baik secara finansial dan ekonomi agar didapatkan pertimbangan yang matang sebelum menerapkan kerjasama maupun pembangunan pasar desa. Pembangunan yang dilakukan tentu saja membawa dampak atau eksternalitas. Dimana eksternalitas adalah aktifitas ekonomi seseorang yang membawa dampak bagi keadaan ekonomi orang lain tidak direfleksikan dalam operasi pasar. Sedangkan menurut (Mangkoesoebroto, 1999) bahwa eksternalitas atau dampak timbul karena tindakan konsumsi atau produksi dari satu pihak mempunyai pengaruh terhadap pihak yang lain dan tidak ada kompensasi yang dibayar oleh pihak yang menyebabkan atau kompensasi yang diterima oleh pihak yang terkena dampak tersebut.

Eksternalitas atau dampak dapat dibagi menjadi dua, yaitu eksternalitas positif dan eksternalitas negatif. Eksternalitas positif adalah dampak yang menguntungkan dari suatu tindakan yang dilakukan oleh suatu pihak terhadap orang lain tanpa adanya kompensasi dari pihak yang diuntungkan, sedangkan eksternalitas negatif apabila dampaknya bagi orang lain yang tidak menerima kompensasi sifatnya merugikan. 
Rahutama, R. | Evaluasi Penerapan Kerjasama Pemerintah-Swasta Dalam Pembangunan Dan Pengelolaan Pasar Desa Penyangkringan - Weleri - Kabupaten Kendal ( Tinjauan Aspek Finansial Dan Aspek Ekonomi )

JPWK 12 (4)

Menurut (Suparmoko, 1997)) bahwa dampak atau eksternalitas pembangunan baik positif maupun negatif perlu untuk diidentifikasi, sedangkan menurut (Soemarwoto, 2007) dampak pembangunan yang dilakukan terbagi menjadi dua yaitu dampak sosial-ekonomi-budaya dan dampak biofisik. Dampak pembangunan dari segi sosial ekonomi yang muncul, menurut (Suratmo, 2007) adalah penyerapan tenaga kerja, berkembangnya struktur ekonomi, peningkatan pendapatan masyarakat, perubahan lapangan pekerjaan, dan kesehatan masyarakat. Dampak secara biofisik terkait dengan adanya kebutuhan akan lahan lokasi pembangunan pasar. Lahan merupakan faktor produksi utama dan barang konsumsi pokok yang dibutuhkan oleh manusia sebagai salah satu kekayaan rumah tangga. Kondisi ini menunjukkan bahwa selain sebagai faktor produksi, lahan dapat juga sebagai komoditas yang dapat dikomersialkan. Semakin mendekati pusat kota biasanya harga lahan semakin tinggi (Randall, 1987 dalam Harini, dkk ,2013).

Dampak sosial ekonomi yang muncul perlu untuk dikuantifikasikan sehingga akan mempermudah didalam analisis ekonomi yang dilakukan. Menurut (Suparmoko dan Suparmoko, 2000) metode penilaian terhadap dampak lingkungan yaitu pendekatan harga pasar, pendekatan dengan nilai barang pengganti atau barang pelengkap, teknik survai. Ada beberapa langkah yang harus ditempuh dalam melakukan penilaian terhadap hasil dari suatu kegiatan atau proyek (Dixon, 1986 dalam Suparmoko dan Suparmoko, 2007) yaitu mengidentifikasi dampak penting dari suatu kegiatan, mengkuantifikasi besarnya dampak tersebut, dan membuat analisis ekonomi.

Metode untuk mengkuantifikasikan besarnya eksternalitas atau dampak yang terjadi adalah dengan menggunakan harga bayangan. Harga bayangan (shadow price) menurut (Pudjo Sumarto, 1991 dalam Safrida dan Hamid, 2013) merupakan suatu harga yang nilainya tidak sama dengan harga pasar, tetapi harga barang tersebut dianggap mencerminkan nilai sosial sesungguhnya dari suatu barang dan jasa. Harga bayangan digunakan untuk menyesuaikan terhadap harga pasar dari beberapa faktor produksi atau hasil produksi.

Kerjasama yang diterapkan didalam pembangunan pasar tentu saja bertujuan untuk memperoleh profit atau keuntungan baik itu dari sisi pemerintah desa maupun dari sisi swasta. Menurut (Sutrisno, 2009) bahwa profitabilitas adalah kemampuan perusahaan dalam menghasilkan keuntungan dengan semua modal yang bekerja didalamnya. Adanya alokasi sumber daya yang efisien diharapkan akan dapat menghasilkan keuntungan atau laba, dimana laba yang didapatkan menurut (Sukirno, 2005) terbagi menjadi dua, yaitu:

- Keuntungan normal, keuntungan normal akan diperoleh bila hasil penjualan totalnya adalah sama dengan biaya total

- Keuntungan luar biasa, dimana keuntungan ini diperoleh bila harga adalah lebih tinggi dari biaya rata-rata yang paling minimum atau hasil penjualannya lebih tinggi daripada biaya total

Analisisis profitabilitas bertujuan untuk mengukur kemampuan perusahaan dalam memperoleh laba. Laba atau profitabilitas sehingga setiap produsen atau kegiatan akan selalu berorientasi kepada keuntungan atau laba, dimana laba atau keuntungan maksimum dapat dicapai dengan dua pendekatan baik dalam jangka pendek maupun jangka panjang (Sukirno, 2005 dan McEachern, 2001), yaitu: 
JPWK 12 (4) Rahutama, R. | Evaluasi Penerapan Kerjasama Pemerintah-Swasta Dalam Pembangunan Dan Pengelolaan Pasar Desa Penyangkringan - Weleri - Kabupaten Kendal ( Tinjauan Aspek Finansial Dan Aspek Ekonomi )

- Pendekatan penerimaan total dan biaya total, atau sering disebut pendekatan total.

- Pendekatan penerimaan marjinal dan biaya marjinal, atau biasa disebut pendekatan marjinal

\section{HASIL DAN PEMBAHASAN}

\section{Identifikasi Kondisi Pasar Penyangkringan}

Secara fisik bahwa secara luas dan kondisi dirasakan baik sesuai dengan hasil kuesioner bahwa $71 \%$ pedagang merasa luasan dan kondisi kios baik dan dapat menunjang aktifitas yang ada. Pasar desa dilihat dari aspek aksesibilitas bahwa akses menuju ke pasar mudah dijangkau dengan kondisi jalan yang lebar dan baik kondisinya. Untuk menunjang aktifitas perdagangan maka dibutuhkan sirkulasi dan pencahayaan yang memadai, hal tersebut sesuai dengan hasil kuesioner yang ada yaitu mayoritas pedagang (86\%) merasakan bahwa sirkulasi dan pencahayaan alami yang ada sudah memadai didalam mendukung aktifitas yang ada. Selain itu penataan komoditas perlu diterapkan dengan harapan dengan adanya penataan komoditas maka akan mempermudah konsumen didalam mendapatkan kebutuhannya. Hasil dari kuesioner juga menunjukkan bahwa $86 \%$ pedagang beranggapan telah ada penataan komoditas yang ada.

Sarana pendukung sesuai dengan Peraturan Menteri Dalam Negeri No 20 Tahun 2012 terdapat tiga belas sarana pendukung, yaitu: Kantor pengelola, Sarana Komunikasi, Penteraan, tempat ibadah dan Pos Keamanan tidak tersedia; Areal parkir dan Areal Bongkar Muat, sudah memadai; Tempat pembuangan sampah sementara/sarana pengelolaan sampah, tersedia tetapi belum memadai; Sanitasi/drainase pada pasar desa dirasakan memadai; Toilet umum, sudah memadai, sedangkan dari kondisinya 86\% pedagang beranggapan kondisi toilet baik; Hidran dan fasilitas pemadam kebakaran, fasilitas pemadam kebakaran tersedia dan memadai oleh pihak pengelola.

\section{Identifikasi Penguasaan dan Pemanfaatan Pasar Desa oleh Pedagang}

Perjanjian kerjasama yang ada juga mengatur hak dan kewajiban masing-masing pihak yang terlibat yaitu pihak Pemerintah Desa Penyangkringan dan PT. Kharisma Agung Sentosa serta diatur juga jangka waktu kontrak pengelolaan Pasar Desa Penyangkringan. Selain itu hak dan kewajiban dari pedagang juga diatur oleh pihak pengelola bersama dengan pemerintah desa. Hak dan kewajiban pedagang adalah sebagai berikut :

- Kewajiban Pedagang:

1. Membayar sewa kios setiap bulannya melalui PT. BPR Mitradana selama 5 tahun

2. Membayar retribusi kebersihan dan keamanan sebesar Rp. 15.000/bulan

- Hak Pedagang :

1. Adanya jaminan didalam pemanfaatan kios sesuai dengan usaha yang diminati

2. Adanya jaminan keamanan dari pihak pengelola

3. Adanya jaminan kebersihan dari pihak pengelola

4. Adanya jaminan ketersediaan dan pemanfaatan fasilitas pendukung yang ada 
Rahutama, R. I Evaluasi Penerapan Kerjasama Pemerintah-Swasta Dalam Pembangunan Dan Pengelolaan Pasar Desa Penyangkringan - Weleri - Kabupaten Kendal ( Tinjauan Aspek Finansial Dan Aspek Ekonomi )

JPWK 12 (4)

Prinsip Penerapan KPS Pembangunan dan Pengelolaan Pasar Desa Penyangkringan Untuk menjamin keberhasilan didalam penerapan kerjasama tersebut maka prinsip yang telah diterapkan adalah adanya kedudukan yang sama; proses pengadaan bersifat terbuka; Adanya transparansi didalam seluruh proses dengan pelibatan dari Badan Permusyawaratan Desa (BPD); Adanya transparansi didalam seluruh proses yang dilakukan akan menjamin tidak adanya persaingan yang tidak sehat antar calon investor; Proses lelang tersebut juga memberikan kepastian hukum karena seluruh proses penawaran sampai dengan penetapan pemenang badan usaha tersebut dapat dipertanggungjawabkan; dan Kerjasama yang tertuang didalam kesepakatan yang ada tidak lepas dari adanya semangat saling mengisi dari kedua belah pihak. Hal ini tercermin dari adanya kerjasama antara pihak pemerintah desa dan pihak swasta mulai dari proses perijinan, sosialisasi maupun pembangunan.

\section{Kendala Penerapan KPS Pembangunan dan Pengelolaan Pasar Desa Penyangkringan} Penerapan kerjasama dalam pembangunan dan pengelolaan pasar desa penyangkringan pada prosesnya tidak berjalan dengan mulus. Hal ini terlihat pada waktu proses penerapannya terdapat kendala-kendala yang ditemui. Kendala-kendala yang dihadapi didalam penerapan kerjasama tersebut adalah kedua belah pihak kurang memegang komitmen didalam proses pelaksanaan kerjasama yang dilakukan. Hal ini terlihat dengan adanya kesepakatan yang belum terpenuhi setelah 3 tahun beroperasinya pasar desa. Kesepakatan yang belum terpenuhi terkait dengan belum tersedianya sarana pendukung pasar yaitu kantor pengelola, tempat pembuangan sampah sementara/sarana pengelolaan sampah, tempat ibadah, pos keamanan, dan fasilitas pemadam kebakaran.

Selain itu kendala yang dihadapi adalah adanya perbedaan sudut pandang antara pihak pemerintah dan swasta, dimana dimana pihak swasta fokus didalam memperoleh keuntungan sebesar-besarnya sedangkan pihak pemerintah tidak fokus didalam mencari keuntungan tapi pemenuhan sarana yang dibutuhkan oleh masyarakat. Proses negosiasi menjadi solusi didalam mengatasi kendala ini dengan tetap berpegang didalam perjanjian atau kesepakatan yang sudah disepakati bersama-sama.

\section{Faktor Keberhasilan Penerapan KPS Pembangunan dan Pengelolaan Pasar Desa Penyangkringan}

Keberhasilan dari penerapan kerjasama tersebut tidak terlepas faktor-faktor yang mempengaruhi nya yaitu adanya pengaturan hak dan kewajiban dari masing-masing pihak yang terlibat yang tertuang didalam perjanjian yang telah disepakati sebelumnya; adanya pelibatan pihak swasta yang memiliki kapasitas dan kapabilitas yang baik dalam bidang konstruksi akan lebih tepat; adanya pelimpahan resiko yang ditanggung kepada pihak swasta berupa dana pembangunan dan pengelolaan pasar desa; dan pemerintah lebih fokus kepada bantuan sosialisasi kerjasama tersebut kepada masyarakat atau calon pedagang yang akan menempati pasar atau yang terkena dampak dalam proses pembangunan dan pengelolaan pasar tersebut.

Keberhasilan penerapan kerjasama juga terlihat dari adanya kondisi fisik bangunan dan sarana pendukung pasar yang tersedia. Hal ini terlihat dari persepsi dari pedagang yang ada yang mayoritas pedagang merasa cukup puas dengan kondisi fisik bangunan, luasan kios, maupun sarana pendukung yang ada. Walaupun tidak 
JPWK 12 (4) Rahutama, R. | Evaluasi Penerapan Kerjasama Pemerintah-Swasta Dalam Pembangunan Dan Pengelolaan Pasar Desa Penyangkringan - Weleri - Kabupaten Kendal ( Tinjauan Aspek Finansial Dan Aspek Ekonomi )

seluruh sarana tersedia pada saat sekarang yaitu kantor pengelola, tempat pembuangan sampah sementara/sarana pengelolaan sampah, tempat ibadah, pos keamanan, dan fasilitas pemadam kebakaran. Lokasi pasar yang strategis serta aksesibilitas yang mudah mendukung aktifitas perdagangan dan jasa yang ada

\section{Analisis Kelayakan Finansial}

Analisis kelayakan finansial yang dilakukan merupakan analisis yang dilihat dari sudut pandang pihak swasta, dimana kita akan melihat dan membandingkan biaya dan manfaat yang akan diperoleh selama masa kerjasama tersebut.

- Biaya proyek pada penelitian ini merupakan biaya-biaya yang dikeluarkan pihak swasta untuk terlaksananya pembangunan Pasar Desa Penyangkringan yang dikelompokkan menjadi biaya investasi, biaya operasional dan biaya pemeliharaan. Biaya-biaya yang dihitung adalah biaya perijinan, biaya konstruksi (persiapan, pekerjaan tanah, pekerjaan pasangan, pekerjaan beton, pekerjaan antar dan kayu, pekerjaan pengecatan, dan biaya tidak terduga), kompensasi kepada pemerintah desa, operasional dan pemeliharaan (gaji pengelola, kebresihan, keamanan, dan pemeliharaan).

- Manfaat proyek pada penelitian ini merupakan manfaat atau keuntungan yang diperoleh pihak swasta selama masa kontrak kerjasama yaitu selama 10 tahun. Manfaat yang diperoleh berupa sewa kios dan retribusi yang dipungut setiap bulannya.

- Analisis kelayakan finansial menggunakan empat kriteria yaitu:

1. Net Present Value (NPV)

Metode ini memperhatikan baik aliran kas netto (Net Cash Flow) yang memperhitungkan "Time Value Money" yaitu dengan adanya tingkat bunga (discount rate) yang ditetapkan $12 \%$ dengan asumsi tidak ada perubahan tingkat suku bunga selama konsesi. Suku bunga tersebut adalah rata-rata dari suku bunga dasar kredit dari beberapa bank yang ada, antara lain BRI, BCA, BNI, Maybak, BCA dan Bank Panin. Hasil perhitungan memperlihatkan bahwa nilai NPV sebesar Rp. 193.610.176,- bernilai positif sehingga pembangunan pasar desa layak untuk dilaksanakan

2. Internal Rate of Return (IRR)

Metode ini merupakan kriteria investasi yang bisa dipakai untuk mengukur persentase keuntungan dari proyek dalam mengembalikan pinjaman. Kita dapat melihat bahwa dengan discount factor sebesar $12 \%$ hasil yang diperoleh sebesar Rp. 193.610.176,-, sedangkan nilai yang diperoleh dengan discount factor sebesar $14 \%$ hasil yang diperoleh sebesar negatif Rp. 69.752.841,-. Oleh karena itu berdasarkan rumus yang ada, maka kita dapatkan nilai IRR adalah $13,5 \%$.

3. Benefit Cost Ratio (BCR)

Benefit Cost Ratio (B/C Ratio) merupakan suatu analisis pemulihan proyek yang biasa diterapkan selain NPV dan IRR . Nilai Net B/C adalah perbandingan antara present value dari net benefit yang positif dengan present value dari net benefit negatif. Dari perhitungan BCR berdasarkan rumus yang ada, maka kita dapatkan nilai $B C R$ sebagai berikut 1,035

4. Pay Back Period

Payback Period adalah salah satu kriteria kelayakan dari suatu kegiatan. Metode Payback Period adalah jangka waktu kembalinya keseluruhan jumlah investasi yang ditanamkan, dihitung mulai dari permulaan proyek sampai 
Rahutama, R. I Evaluasi Penerapan Kerjasama Pemerintah-Swasta Dalam Pembangunan Dan Pengelolaan Pasar Desa Penyangkringan - Weleri - Kabupaten Kendal ( Tinjauan Aspek Finansial Dan Aspek Ekonomi )

JPWK 12 (4)

dengan arus nilai bersih produksi tambahan sehingga mencapai jumlah keseluruhan investasi kapital yang ditanamkan. Dari perhitungan PBP, maka kita dapatkan nilai PBP sebagai berikut tahun ke-4 bulan ke-3

\section{Analisis Kelayakan Ekonomi}

Analisis kelayakan ekonomi yang dilakukan merupakan analisis yang dilihat dari sudut pandang pihak pemerintah desa, dimana kita akan melihat dan membandingkan biaya dan manfaat yang akan diperoleh selama masa kerjasama tersebut.

- Biaya proyek pada penelitian ini merupakan biaya-biaya yang dikeluarkan pihak pemerintah atau biaya yang ditanggung oleh masyarakat umum selama proses pembangunan Pasar Desa Penyangkringan maupun pasca beroperasinya pasar tersebut atau biaya sosial. Biaya yang ditanggung adalah biaya akibat adanya polusi udara yang timbul pada saat konstruksi maupun pasca beroperasinya pasar yang dialami oleh pedagang yang ada. Sedangkan biaya yang lainnya adalah adanya kerugian akibat alih fungsi lahan pertanian. Alih fungsi lahan pertanian terjadi karena lahan yang diperlukan untuk pembangunan pasar merupakan lahan pertanian berupa sawah. Selain itu biaya akibat hilang kesempatan yang hilang yaitu kesempatan kerja (petugas parkir) dan potensi parkir yang hilang, kemudian biaya konstruksi dengan menggunakan harga bayangan.

- Manfaat proyek pada penelitian ini merupakan manfaat atau keuntungan yang diperoleh pihak pemerintah atau masyarakat selama masa kontrak kerjasama yaitu selama 10 tahun. Manfaat yang didapatkan yaitu terdapatnya penyerapan tenaga kerja pada saat konstruksi yang merupakan tenaga kerja di sekitar lokasi pasar, peningkatan kesejahteraan tersebut tercermin dari adanya peningkatan pendapatan yang diperoleh dengan adanya aktifitas ekonomi tersebut, berkembangnya struktur ekonomi baru yaitu munculnya lapangan kerja baru yang terlihat dari adanya perekrutan tenaga kerja sebagai karyawan kios di pasar desa, retribusi yang menjadi hak dari Pemerintah Desa Penyangkringan adalah retribusi KM/WC, selain itu manfaat yang didapat secara finansial.

- Analisis kelayakan ekonomi

Analisis tersebut menggunakan empat kriteria yaitu

\section{Net Present Value (NPV)}

Metode ini memperhatikan baik aliran kas netto (net cash flow) yang memperhitungkan time value money yaitu dengan adanya tingkat bunga (discount rate) yang ditetapkan. Menurut (Kadariah, 1999 dan Gray, dkk, 2005) bahwa Social Opportunity Cost of Capital yang digunakan sebagai discount rate di Indonesia adalah antara 10-15\% dengan asumsi tidak ada perubahan tingkat suku bunga selama konsesi. Oleh karena itu ditetapkan discount rate didalam penelitian ini adalah sebesar $10 \%$. Hasil perhitungan memperlihatkan bahwa nilai NPV sebesar Rp. 143.437.317,- bernilai positif sehingga pembangunan pasar desa layak untuk dilaksanakan

\section{Internal Rate of Return (IRR)}

Metode ini merupakan kriteria investasi yang bisa dipakai untuk mengukur persentase keuntungan dariproyek dalam mengembalikan pinjaman. Kita dapat melihat bahwa dengan discount factor sebesar 10\% hasil yang diperoleh sebesar Rp. 143.437.317,-, sedangkan nilai yang diperoleh dengan discount factor $12 \%$ hasil yang diperoleh sebesar negatif Rp. 32.886.737,--. Oleh karena itu berdasarkan rumus yang ada, maka kita dapatkan nilai IRR adalah 11,6\%. 
JPWK 12 (4) Rahutama, R. | Evaluasi Penerapan Kerjasama Pemerintah-Swasta Dalam Pembangunan Dan Pengelolaan Pasar Desa Penyangkringan - Weleri - Kabupaten Kendal ( Tinjauan Aspek Finansial Dan Aspek Ekonomi )

\section{Benefit Cost Ratio (BCR)}

Benefit Cost Ratio (B/C Ratio) merupakan suatu analisis pemulihan proyek yang biasa diterapkan selain NPV dan IRR. Nilai Net B/C adalah perbandingan antara present value dari net benefit yang positif dengan present value dari net benefit negatif. Dari perhitungan $B C R$ berdasarkan rumus yang ada, maka kita dapatkan nilai $B C R$ sebagai berikut 1,01

\section{Pay Back Period}

Payback Period adalah salah satu kriteria fisibilitas atau kelayakan dari suatu kegiatan. Dimana metode Payback Period adalah jangka waktu kembalinya keseluruhan jumlah investasi yang ditanamkan, dihitung mulai dari permulaan proyek sampai dengan arus nilai netto produksi tambahan sehingga mencapai jumlah keseluruhan investasi kapital yang ditanamkan. Dari perhitungan PBP berdasarkan rumus yang ada, maka kita dapatkan nilai PBP sebagai berikut tahun ke-4 bulan ke-4.

\section{Evaluasi Penerapan Kerjasama Pemerintah-Swasta dalam Pembangunan dan Pengelolaan Pasar Desa Penyangkringan}

Analisis finansial yang dilihat dari sisi pihak swasta dan analisis ekonomi yang dilihat dari kacamata pemerintah desa yang telah dilakukan dapat dilihat bahwa dari perhitungan untuk semua kriteria yaitu NPV, IRR, BCR dan PBP menunjukkan pembangunan Pasar Desa Penyangkringan layak dibangun. Kriteria $B C R$ terlihat baik dari sisi ekonomi maupun sisi finansial memperlihatkan nilai yang positif yaitu 1,035 dan 1,01 yang berarti investasi yang dikeluarkan akan dapat memberikan manfaat yang lebih banyak dalam pembangunan dan pengelolaan Pasar Desa Penyangkringan. Hal ini menjadi salah satu pertimbangan bagi pemerintah desa didalam mengambil keputusan untuk menerapkan kerjasama dengan pihak swasta. Selain itu dari kriteria IRR juga menunjukkan bahwa nilai IRR positif yaitu 13,5\% (finansial) dan $11,6 \%$ (ekonomi), hal ini menunjukkan bahwa pembangunan pasar desa layak untuk dilanjutkan karena nilai IRR lebih besar dari nilai discount factor yang digunakan baik dari sisi finansial (12\%) maupun sisi ekonomi (10\%).

Sedangkan dari kriteria PBP terlihat bahwa secara finansial modal yang dikeluarkan oleh pihak investor akan kembali pada bulan ke-3 tahun ke-4, sedangkan dari sisi ekonomi atau dari sisi pemerintah desa yaitu pada bulan ke-4 tahun ke-4. Adanya masa pengembalian modal yang lebih cepat daripada jangka waktu kontrak tersebut menunjukkan bahwa dari sisi finansial dan ekonomi menunjukkan kelayakan karena masa PBP lebih rendah dari masa perjanjian kerjasama. Masa PBP dari sisi ekonomi juga memperlihatkan bahwa secara ekonomi pembangunan dan pengelolaan pasar desa layak dikarenakan dapat memberikan dampak positif terhadap perekonomian masyarakat selama pra dan pasca proses pembangunan.

Akan tetapi berdasarkan perhitungan PBP dimana modal yang telah dikeluarkan oleh investor dapat kembali dalam jangka waktu 4 tahun 3 bulan, sehingga sisa masa kontrak yaitu 5 tahun 7 bulan pihak investor akan mendapatkan keuntungan dari pengelolaan pasar desa tersebut. Adanya sisa waktu selama 5 tahun 7 bulan mengindikasikan bahwa pihak investor diberikan keuntungan yang lebih daripada pihak pemerintah desa, hal ini terlihat dari pihak investor diberikan masa keuntungan yang melebihi masa PBP. 
Rahutama, R. I Evaluasi Penerapan Kerjasama Pemerintah-Swasta Dalam Pembangunan Dan Pengelolaan Pasar Desa Penyangkringan - Weleri - Kabupaten Kendal ( Tinjauan Aspek Finansial Dan Aspek Ekonomi )

JPWK 12 (4)

Keuntungan yang melebihi PBP yaitu mulai pada bulan ke-4 tahun ke-4 sampai dengan selesai merupakan keuntungan yang supernormal, hal ini sesuai dengan teori ekonomi yang ada bahwa keuntungan supernormal dicapai diperoleh bila harga adalah lebih tinggi dari biaya rata-rata yang paling minimum atau hasil penjualannya lebih tinggi daripada biaya total. Keuntungan normal pihak swasta sebenarnya sudah dicapai pada saat break even point (BEP) yang terlihat dari penjualan totalnya adalah sama dengan biaya total.

Pembangunan dan pengelolaan pasar desa dengan skema bangun-guna-serah antara pihak Pemerintah Desa Penyangkringan dan PT. Kharisma Agung Sentosa menunjukkan bahwa dengan terbangunnya pasar desa akan memberikan keuntungan kepada pihak-pihak yang terlibat. Keuntungan dari sisi investor tentu saja berupa keuntungan atau laba dari modal yang telah dikeluarkan dengan melihat dari modal/biaya yang dikeluarkan, resiko yang harus dihadapi, suku bunga sebagai dasar perhitungan (discount factor sebesar 12\%) maupun manfaat yang akan diperoleh.

Sedangkan keuntungan dari pihak Pemerintah Desa Penyangkringan tidak saja bagi pemerintah desa sendiri akan tetapi memberikan keuntungan lebih luas yaitu manfaat sosial atau dampak positif yang timbul dengan berdirinya pasar desa tersebut berupa adanya lapangan kerja dan peningkatan kesejahteraan bagi pedagang yang ada. Sedangkan biaya yang diperhitungkan adalah dampak negatif atau biaya sosial yang timbul dari adanya pembangunan pasar tersebut maupun kesempatan yang hilang dari adanya pembangunan pasar tersebut. Dalam perhitungan kelayakan ekonomi dari sisi pemerintah akan mengacu kepada suku bunga sosial yang digunakan di negara berkembang termasuk Indonesia sebesar 10\% dan menggunakan harga bayangan didalam menilainya.

Keuntungan yang diharapkan oleh pihak pemerintah desa tidak hanya secara ekonomis yaitu memberikan pendapatan kepada pemerintah desa, karena lahan merupakan aset desa tapi manfaat sosial. Manfaat tersebut seringkali tidak mudah terlihat atau mudah dihitung. Manfaat sosial yang timbul seringkali tidak dapat secara langsung dapat dirasakan seperti adanya peningkatan pendapatan yang berujung kepada peningkatan kesehatan dan kesejahteraan pedagang maupun pihak-pihak yang secara langsung maupun tidak langsung terlibat didalam aktifitas yang ada di Pasar Desa Penyangkringan.

Salah satu kriteria didalam menganalisis kelayakan adalah kriteria PBP yang memperlihatkan seberapa cepat modal atau investasi akan kembali tanpa memperhatikan nilai waktu dari uang. Dimana kriteria ini dapat memperlihatkan waktu nilai impas yang akan diperoleh, dan hasil analisis finansial menunjukkan nilai impasnya adalah pada tahun ke-4 bulan ke-3. Hal ini tentu menarik pihak swasta karena modal akan kembali kurang dari masa kontrak yang ditawarkan oleh pihak pemerintah yaitu selama 10 tahun dan disepakati oleh kedua belah pihak.

Sedangkan dari sisi ekonomi nilai impasnya adalah pada tahun ke-4 bulan ke-3 yang tidak terpaut jauh dari analisis PBP secara finansial. Hal ini memperlihatkan bahwa dari sisi ekonomi pun nilai PBP kurang dari masa kontrak yang ditawarkan oleh pihak pemerintah terhadap calon investor. Nilai PBP seharusnya menjadi tolok ukur didalam 
JPWK 12 (4) Rahutama, R. | Evaluasi Penerapan Kerjasama Pemerintah-Swasta Dalam Pembangunan Dan Pengelolaan Pasar Desa Penyangkringan - Weleri - Kabupaten Kendal ( Tinjauan Aspek Finansial Dan Aspek Ekonomi )

pemerintah menentukan jangka waktu kontrak pengelolaan Pasar Desa Penyangkringan dengan skema bangun-guna-serah (BGS) yang dipilih.

Kriteria PBP akan terkait dengan penetapan jangka waktu kontrak antara pihak pemerintah desa dengan pihak swasta, dimana dari hasil perhitungan menunjukan bahwa perjanjian kerjasama yang ada terlalu condong kepada pihak investor yang terlihat dari lamanya pihak swasta mendapatkan keuntungan sehingga swasta mendapatkan keuntungan supernormal. Pada kerjasama didalam pembangunan dan pengelolaan Pasar Desa Penyangkringan terlihat pihak Pemerintah Desa Penyangkringan tidak menghitung kelayakannya, sehingga kerjasama yang ada kurang memberikan keuntungan kepada pihak pemerintah desa.

Penetapan waktu kerjasama juga harus mempertimbangkan sisi finansial agar pihak swasta atau investor tertarik didalam berinvestasi untuk pembangunan dan pengelolaan pasar desa. Sedangkan pihak pemerintah juga harus menghitung kelayakannya sehingga tidak dirugikan selama masa kerjasama tersebut. Penetapan waktu kerjasama dapat berdasarkan dari nilai PBP sehingga dalam proses negosiasi dapat ditemukan jangka waktu yang optimal.

\section{KESIMPULAN}

Penerapan kerjasama dengan skema BGS dapat dilakukan dengan menerapkan prinsip-prinsip yang ada serta faktor-faktor penentu keberhasilan penerapannya. Walaupun tidak menutup kemungkinan adanya kendala yang dihadapi. Adanya persepsi pedagang yang mayoritas puas dengan bangunan fisik dan sarananya turut mendukung keberlangsungan pasar desa. Untuk mendukung penerapan kerjasama tersebut maka perlu dilakukan analisis finansial dan analasis ekonomi sehingga dapat menjadi pertimbangan didalam menentukan jangka waktu kontrak yang sesuai. Dimana hasil analisis menunjukkan layak baik dari sisi finansial maupun ekonomi. Untuk menentukan jangka waktu kontrak yang menjadi dasar utama adalah kriteria PBP yang menunjukkan jangka waktu kerjasama saat ini terlalu lama yang memberikan keuntungan supernormal kepada pihak swasta.

\section{DAFTAR PUSTAKA}

Arikunto, Suharsimi. 2010. Prosedur Penelitian Suatu Pendekatan Praktik. Jakarta : PT. Rineka Cipta

Bebeșelea, M. (2010). The accounting and financial flow of taxes in Romania. Cluj Napoca: Alma Mater Publishing House

Gray, Clive, dkk. 2005. Pengantar Evaluasi Proyek Edisi Kedua. Jakarta : PT. Gramedia Pustaka Utama

Handley, Paul.1997. A Critical View Of The Build-Operate-Transfer Privatisation Process In Asia. Bangkok : Asian Journal Of Public Administration. Vol. 19 (2)

Harini, Rika, dkk. 2013. Nilai Ekonomi Total Konversi Lahan Pertanian Di Kabupaten Sleman. Jurnal Manusia Dan Lingkungan, Vol. 20, No.l, Maret. 2013:35-48

Kadariah, Karlina, Lien, dan Gray, Clive. 1999. Pengantar Evaluasi Proyek . Jakarta: Lembaga Penerbit FE UI 
Rahutama, R. I Evaluasi Penerapan Kerjasama Pemerintah-Swasta Dalam Pembangunan Dan Pengelolaan Pasar Desa Penyangkringan - Weleri - Kabupaten Kendal ( Tinjauan Aspek Finansial Dan Aspek Ekonomi )

Khalik R, Safrida dan A.Humam Hamid. 2013. Optimasi Pola Tanam Usahatani Sayuran Selada Dan Sawi Di Daerah Produksi Padi. Agrisep Vol (14) No.1

Peraturan Menteri Dalam Negeri Republik Indonesia Nomor 20 tahun 2012 tentang Pengelolaan Dan Pemberdayaan Pasar Tradisional

Peraturan Presiden No. 67 Tahun 2005 tentang KERJASAMA PEMERINTAH DENGAN BADAN USAHA DALAM PENYEDIAAN INFRASTRUKTUR

Peraturan Bupati No. 65 Tahun 2015 tentang pedoman pemanfaatan asset desa di kabupaten kendal

Sanusi, Bachwawi. 2000.Pengantar Evaluasi Proyek. Jakarta: Fakultas Ekonomi UI

Setiawan, Tomi Dan Sukma F, Egnas. 2012. Public Private Partnership as a Public Service Dilemma. Jawa Barat : International Journal of Administrative Science \& Organization. Vol 19 (3)

Soemarwoto, Otto. 2007. Analisis Mengenai Dampak Lingkungan. Yogyakarta : Gadjah Mada University Press

Sukirno, Sadono. 2005 Mikro Ekonomi Teori Pengantar. Jakarta : PT. Raja Grafindo Persada

Suparmoko, M. 1997. Ekonomi Sumberdaya Alam dan Lingkungan ( Suatu Pendekatan Teoritis). Yogyakarta : BPFE

Suparmoko, M dan Suparmoko, Maria R. 2000. Ekonomi Lingkungan Edisi Pertama. Yogyakarta: BPFE

Suratmo, F Gunarwan. 2007. Analisis Mengenai Dampak Lingkungan. Yogyakarta : Gadjah Mada University Press

Sutrisno. 2009. Manajemen Keuangan Teori Konsep dan Aplikasi, Cetakan Ketujuh. Yogyakarta : Ekoisia.

Undang-Undang No 6 Tahun 2014 tentang Desa 